\title{
マグネサイトの熱分解と焼結
}

\author{
呉 基 東・森川日出貴・岩井津一・青木秀 希* \\ (東京工業大学 工業材料研究所, * 東京医科歯科大学 医用器材研究所)
}

\section{Thermal Decomposition and Sintering of the Synthesized Magnesite}

By

Ki-Dong OH, Hideki MORIKAWA, Shin'ichi IWAI and Hideki AOKI*

(Research Laboratory of Engineering Materials, Tokyo Institute of Technology, * Institute for Medical and Dental Engineering, Tokyo Medical and Dental University)

\begin{abstract}
Sintering process of the heat treated product of the synthesized magnesite at temperatures between $450^{\circ}$ and $1500^{\circ} \mathrm{C}$ with the intervals $100^{\circ} \mathrm{C}$ in air and the resulting materials were studied by the X-ray powder diffraction and scanning electron microscopy.

It was found that the product at $600^{\circ} \mathrm{C}$ was identified as periclase and these small magnesia particles began to sinter each other with increasing rapidity at about $1100^{\circ} \mathrm{C}$. The pseudorhombohedral shape of the magnesite was almost retained after it was heated at $1500^{\circ} \mathrm{C}$.

The particles of the magnesia increased in size and the lattice dimension decreased with increasing temperatures. High preferred orientation of the magnesia crystallite with respect to the original magnesite was revealed from electron diffraction and $\mathrm{X}$-ray oscillation photograph.
\end{abstract}

[Received November 12, 1973]

\section{1. 緒 言}

マグネサイト $\left(\mathrm{MgCO}_{3}\right)$ は $1500^{\circ} \mathrm{C}$ 以上の高温で硬 焼してマグネシア・クリンカーとなし, 各種の塩基性耐 火物の原料として用いられる。また，軽焼したものはマ グネシア・セメントなどに用いられている.

マグネサイトの加熱変化やマグネシアの焼結に関する 研究は, 古くから多くの研究者により行なわれている. 例えば, Pande ら”は天然マグネサイトについて電子顕 微鏡観察と電子線回折による研究の結果から, マグネサ イトの熱分解とマグネシアの焼結の 過程を報告してい る. また, Daniels ら ${ }^{2)}$ は酸化マグネシウム試薬につい て, 焼結過程を反応速度論的に研究している。橋本ら ${ }^{3)}$ は天然マグネサイトを種々の雾囲気条件で加熱し，その 熱分解について沃素の吸着による比表面積とX線による 結晶子の大きさから算出したそれとを比較検討してい る.また, Obst ら"1)はドロマイトとカルサイトを $500^{\circ} \mathrm{C}$ から $1500^{\circ} \mathrm{C}$ の温度に加熱処理し, 晶出したマグネシア とカルシアの粒子の形態とその成長について走查型電子 顕微鏡により観察している。

しかし，天然のマグネサイトを試料とした場合には， 必ず不純物が含まれているので, その脱炭酸ガス過程や 焼結過程に不純物の影響があることを考慮しなければな らない、また, 試薬の炭酸マグネシウムや酸化マグネシ
ウムを用いた場合には，粒子が微細なために単結晶によ る研究法が適用できないので, 反応のトポタキシー的な 効果を知ることは困難である.

筆者らは水熱合成法によって, 純粋な大きさ約 60 $100 \mu$ の透明な自形をしたマグネサイト ${ }^{5)}$ の結晶を合成 することができたので，この結晶を用いて以下の実験を 行なった.この合成マグネサイトを空気中で $450^{\circ} \sim 1500$ ${ }^{\circ} \mathrm{C}$ までの間の温度で加熱し, その脱炭酸によって晶出 したマグネシアの焼結過程を熱分析, 走查型電子顕微鏡 観察, 電子線回折, 粉末 X線回折および単結晶 X線法に より検討した.

\section{2. 実験}

マグネサイトは, 特級試薬の $\mathrm{MgCl}_{2}$ と $\mathrm{Na}_{2} \mathrm{CO}_{3}$ の 濃度 $0.5 \sim 1.0 \mathrm{~mol} / l$ の水溶液を等モル 等量混合して出 発物質とし，これをパイレックス製のガラス管を内装し た容積 $100 \mathrm{~m} l$ のテストチューブ型オートクレーブに入 れ, $180^{\circ} \sim 200^{\circ} \mathrm{C}$ (水蒸気圧 $9.9 \sim 15.3 \mathrm{~atm}$ に相当) で $72 \sim 144$ 時間水熱処理して合成した. このマグネサイト を白金坩堝に入れ, $450^{\circ} \sim 1500^{\circ} \mathrm{C}$ の温度範囲に $100^{\circ} \mathrm{C}$ の間隔で加熱した. $450^{\circ} \sim 900^{\circ} \mathrm{C}$ までの加熱はカンタル 線電気炉で, $950^{\circ} \sim 1500^{\circ} \mathrm{C}$ までの加熱はシリコニット 発熱体電気炬で行なった. 各試料は昇温速度 $4^{\circ} \mathrm{C} / \mathrm{min}$ 
で加熱し, 所定温度に達した後, 約 12 時間保持した後 デシケータの中で放冷した.

\section{3. 実 験 結 果}

\section{1 熱分析}

図-1 に, 昇温速度 $5^{\circ} \mathrm{C} / \mathrm{min}$ で測定したマグネサイト の TGA と DTA の曲線を示す. この TGA の曲線を 見ると $510^{\circ} \mathrm{C}$ 付近より炭酸ガスの逸脱が起り，約 660 ${ }^{\circ} \mathrm{C}$ で分解反応は終っている. また, DTA 曲線には 610 ${ }^{\circ} \mathrm{C}$ 付近にピークを有する吸熱曲線が見られる.

\section{$3.2 \mathrm{X}$ 線回折}

次に各温度段階の試料について，粉末 X線法によって 生成物の同定を行ない，格子定数および回折線の拡がり から結晶子の大きさを算出した．X線の測定は波高分析 器を備えたシンチレーションカウンタと $\mathrm{Ni}$ フィルタで 沪過した $\mathrm{CuK}_{\alpha}$ 線を用い, $40 \mathrm{kV}, 20 \mathrm{~mA}$ で行なった。

$450^{\circ} \sim 1500^{\circ} \mathrm{C}$ までの加熱物の 同定を粉末 X線回折法 により行なった. $450^{\circ} \sim 550^{\circ} \mathrm{C}$ に加熱したものは弱いマ グネサイトのピークが認められた. $600^{\circ} \mathrm{C}$ 以上の加熱物 はすべてマグネシアと同定された. $600^{\circ} \sim 900^{\circ} \mathrm{C}$ に加熱 した各試料の粉末 X線パターンは鋭い回折ピークを示し ている.

次に回折線の拡がりから結晶子の大きさを求めた. 用 いた回折線はマグネシアの (200) で, $1500^{\circ} \mathrm{C}$ に加熱した 試料のマグネシアのそれを標準線とし, Jones ${ }^{6}$ と Alexander $^{7}$ らの方法によって，装置に由来する拡がりを除 去し, 結晶子の大きさを Debye Scherrer の式 $D_{h k l}=$ $K \lambda / \beta_{1 / 2} \cos \theta$ によって算出した. 式中の因子 $K$ は $\beta$ の 測定法とおもに測定物の形状に依存している. 球状の場 合, Scherrer $^{8)}$ は $K=0.89$ と, 立方体の場合 Patterson ${ }^{9}$ は $K=1.11$ と報告しているので, Birks ら ${ }^{10)}$ は $K=1.0$ を折衣案として適用している. 本実験の電子顕微鏡観察 により，生成物の形状は球や立方体をなしていないので $K=1.0$ を用いた.ここで入は $\mathrm{CuK}_{\alpha}$ の波長( $(\AA), \beta_{1 / 2}$

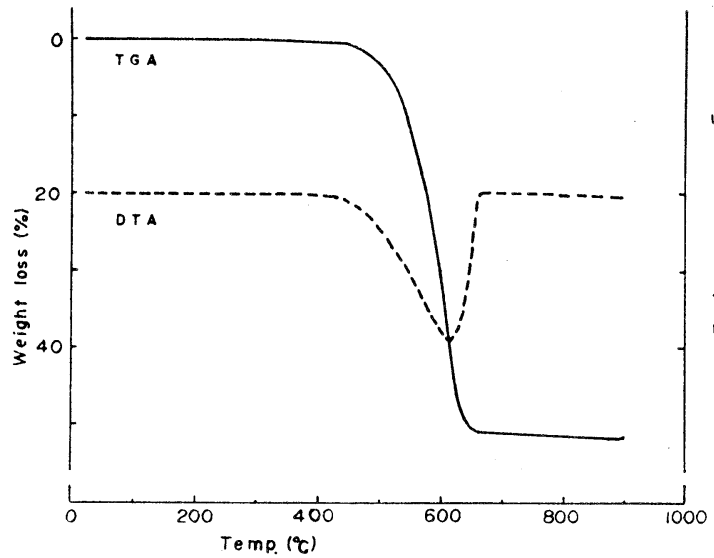

Fig. 1. DTA and TGA curves of magnesite.

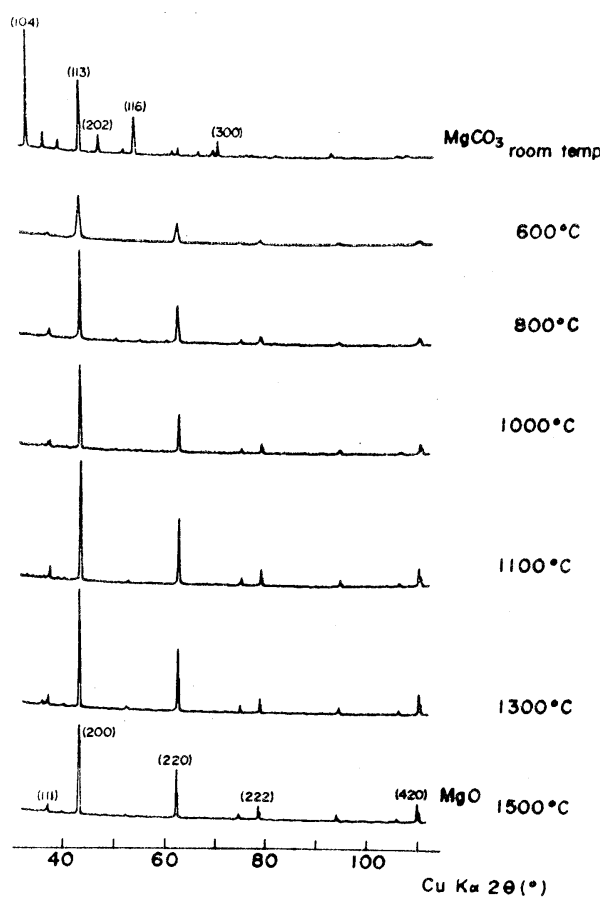

Fig. 2. X-ray powder diffraction patterns of heated magnesite.

は回折線の半価幅 ( $\mathrm{rad}), D$ は結晶子の大きさ (̊̊) で ある.その結果を表-1 に示した。

Cimino ら ${ }^{11}$ は試薬の炭酸マグネシウムを $500^{\circ} \sim 1000$ ${ }^{\circ} \mathrm{C}$ の間で炍焼し, 結晶子の大きさを報告している，彼 らのデータは $800^{\circ} \sim 1000^{\circ} \mathrm{C}$ の間では, 結晶子の大きさ は約 $500 \AA$ であるのに対して, 本研究のデータはその 温度範囲で，温度の上昇と共に結晶子の大きさは急激に 大きくなっている.

\section{3 格子定数}

Table 1. Particle size of magnesium oxide as a function of heating temperature.

\begin{tabular}{cccc}
\hline Sample No. & $\begin{array}{c}\text { Heating temp. } \\
\left({ }^{\circ} \mathrm{C}\right)\end{array}$ & $\begin{array}{c}\text { Heating time } \\
(\mathrm{h})\end{array}$ & $\begin{array}{c}\text { Particle size from } \\
\text { X-ray data }(\AA)\end{array}$ \\
\hline 1 & 600 & 14.5 & 260 \\
2 & 700 & 14.9 & 380 \\
3 & 800 & 15.3 & 760 \\
4 & 900 & 15.8 & 1100 \\
5 & 1000 & 16.2 & - \\
\hline
\end{tabular}

Table 2. Lattice dimension of magnesium oxide as a function of heating temperature.

\begin{tabular}{ccc}
\hline Sample No. & Heating temp. $\left({ }^{\circ} \mathrm{C}\right)$ & Lattice dimension $a_{0}(\AA)$ \\
\hline 1 & 600 & $4.2165 \pm 0.0005$ \\
2 & 700 & $4.2153 \pm 0.0004$ \\
3 & 800 & $4.2142 \pm 0.0005$ \\
4 & 900 & $4.2123 \pm 0.0004$ \\
5 & 1000 & $4.2124 \pm 0.0003$ \\
6 & 1100 & $4.2130 \pm 0.0006$ \\
7 & 1200 & $4.2119 \pm 0.0002$ \\
8 & 1300 & $4.2116 \pm 0.0001$ \\
\hline
\end{tabular}




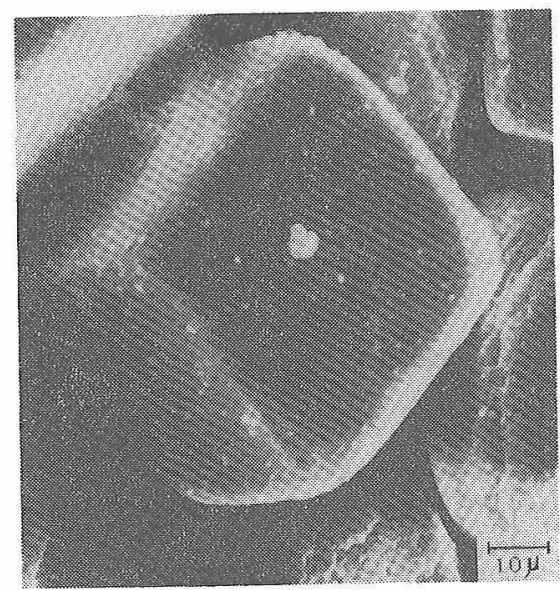

(a) magnesite single crystals

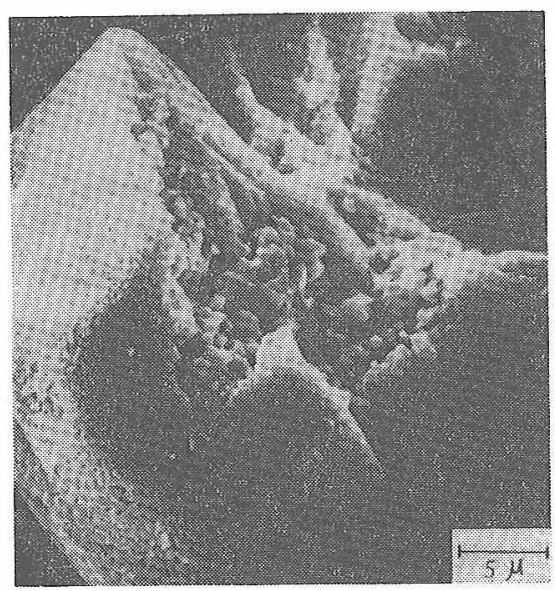

(c) magnesite heated at $1000^{\circ} \mathrm{C}$

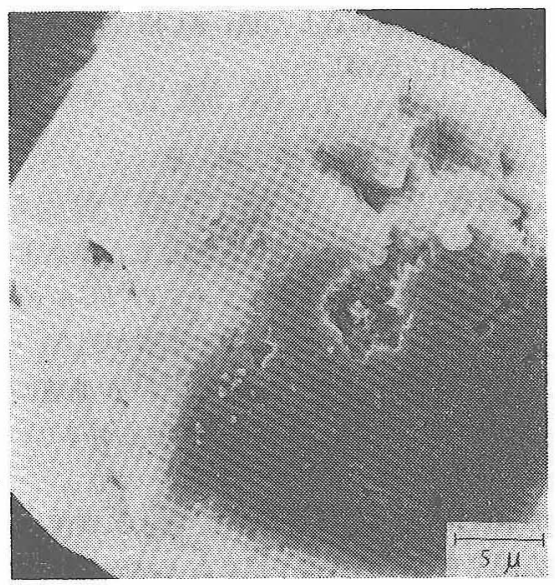

(b) magnesite heated at $600^{\circ} \mathrm{C}$

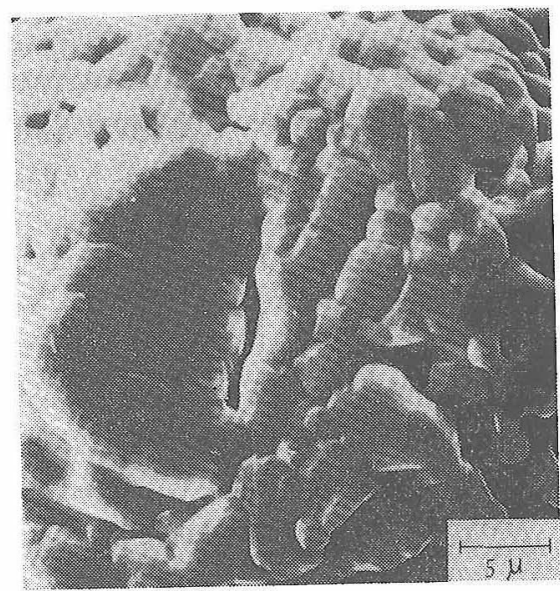

(d) magnesite heated at $1500^{\circ} \mathrm{C}$

Fig. 3. Scanning electron micrographs of heated magnesite.

各加熱試料について格子定数の精密測定を行なった. 測定は $99.99 \%$ の金属 Si を標準として反射觔度の補正 を行ない，格子定数を算出した. 走査速度は $1 \% / 4$ 分とし た. UNICS プログラム ${ }^{12)}$ 用いて，3〜7個の回折線 の角度から最小 2 乗法により格子定数を計算した．その

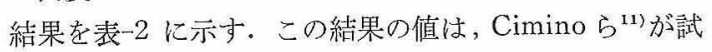
薬の炭酸マグネシウムを熱分解して生成したマグネシア の格子定数值よりわずかに大きい，格子定数は加熱温度 の上昇につれて徐从に減少して打り, Cimino らの值は $800^{\circ} \mathrm{C}\left(800^{\circ} \mathrm{C}\right.$ で $4.211 \AA$ Å) 以上でほぼ一定となり, 筆 者らが測定した値は $900^{\circ} \mathrm{C}\left(900^{\circ} \mathrm{C} て ゙ ~ 4.2123 \AA\right)$ 以上 でほぼ一定となる。

\section{4 走㚗型電子顕微鏡観察}

図-3にもとのマグネサイト, $600^{\circ} \mathrm{C}$ 加熱物, $1000^{\circ} \mathrm{C}$ 加 熱物, $1500^{\circ} \mathrm{C}$ 加熱物の走查型電子顕微鏡写真を示した. もとのマグネサイトの表面はなめらかであるのに対して $450^{\circ} \mathrm{C}$ に加熱したものは表面の所々に凹凹ができてお り， $\mathrm{CO}_{2}$ の逸脱が始まっているものと考えられる，600 ${ }^{\circ} \mathrm{C}$ では表面の凹凸と約 $1 \mu$ の孔が観察された。 $700^{\circ} \mathrm{C}$
に加熱したものでは，もとのマグネサイトの仮像をした マグネシアの各々の粒子と無数に多くの空隚が観察され た. $800^{\circ} \mathrm{C}$ 扔よび $900^{\circ} \mathrm{C}$ で加熱したものは，その粒子 の大きさが $700^{\circ} \mathrm{C}$ の場合に比べて幾分大きくなってい る. $1000^{\circ} \mathrm{C}$ では粒子の成長がさらに進み, 粒子の大きさ は $0.3 \sim 0.5 \mu$ になっている. $1100^{\circ} \mathrm{C}$ 以上の温度ではマ グネシアの粒子は冽りの粒子と接触して粒界の空隙が減 っているのが認められた．これはX線の回折ピークが鋭 くなることと符合するものである. $1500^{\circ} \mathrm{C}$ に加熱した ものは $1200^{\circ} \mathrm{C} と 1300^{\circ} \mathrm{C}$ に加熱したものとほぼ同じ傾 向を示しているが，粓子の大きさは $3 \sim 7 \mu$ まで大きく 成長している.

Pande ら ${ }^{11}$ は試薬の炭酸マグネシウムと天然産マグネ サイトを $1050^{\circ} \mathrm{C}$ までの温度で炍煋し, その加熱物を電 子顕微鏡で観察している、試薬の炭酸 マグネシウムは $900^{\circ} \mathrm{C}$ の加熱で, また，天然マグネサイトは $900^{\circ} \sim 1000$ ${ }^{\circ} \mathrm{C}$ の加熱で立方体の結晶の生成を認めている。これら の立方体結晶の大きさは $0.1 〜 0.35 \mu$ であったと報告し ている. 


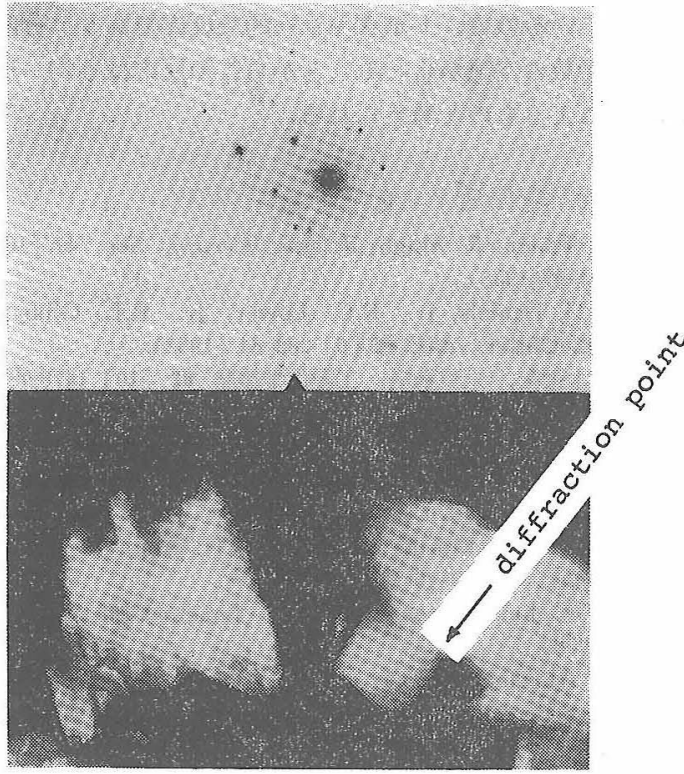

Fig. 4. Electron diffraction pattern of periclase produced by heating magnesite at $1300^{\circ} \mathrm{C}$.

Eubank ら ${ }^{13}$ ) は試拲の炭酸マグネシウムを加熱して得 たマグネシアの電子顕微鏡峴察による大きさは $1000^{\circ} \mathrm{C}$ で $0.1 \mu, 1300^{\circ} \mathrm{C}$ で $0.5 \mu$ であったと報告している. 化学的に純粋な単結晶マグネサイトを出発物質とした本 実験では， $1000^{\circ} \mathrm{C}$ でマグネシア粒子の大きさが $0.3 \sim$ $0.5 \mu$ に成長しており，他の出発物質の場合よりもやや 大きい，これは $1000^{\circ} \mathrm{C}$ 以下の場合に，X線で測定した 結晶子の大きさが他の報告よりも大きいことと符合して いる.また, $1300^{\circ} \mathrm{Cでは} 1.5 \sim 2.5 \mu$ に成長し, これは 上記の Eubank らの場合よりも大きい. $1500^{\circ} \mathrm{C}$ では 6 $\sim 7 \mu$ に成長する.

次に，このマグネサイトの分解反応のトポタキシー的 な效果を検討するために，マグネサイトの仮像をしたマ グネシアについて単結晶X線法によりマグネシアの配向

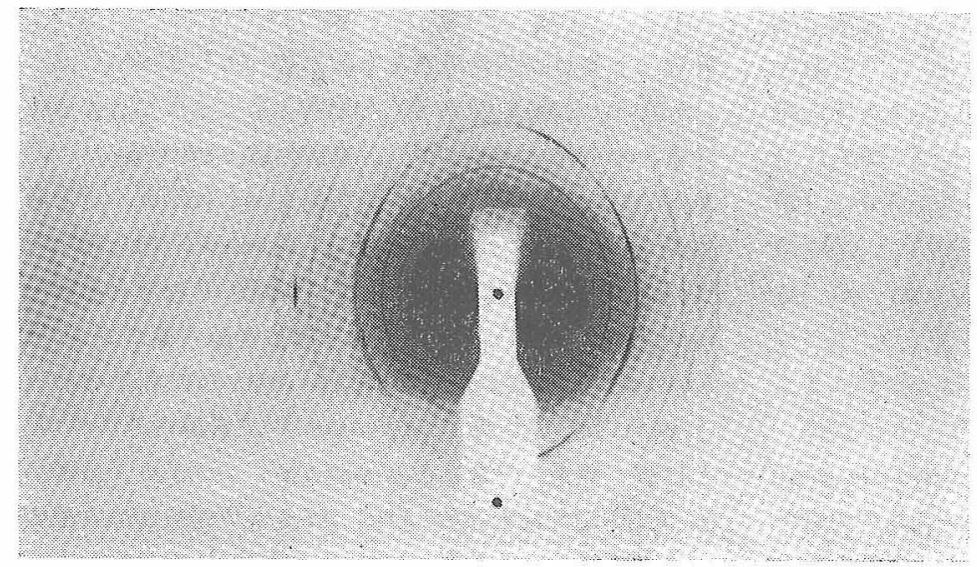

Fig. 5. [1릭 axis oscillation photograph of heated magnesite at $800^{\circ} \mathrm{C}$ showing diffraction from periclase.
性を調べた、図-4に $1300^{\circ} \mathrm{C}$ の加熱物の破磁片を加速 電圧 $75 \mathrm{kV}$ で撮った電子頙微鏡像ならびに㤀の制限視 野電子回折像走す。东た，図 -5 には $800^{\circ} \mathrm{C}$ に加熱し たマグネサイトのX線振動写真走示寸。これはもとのマ グネリイトの [120] を回転軸にして撮ったものである。

\section{4. 考 察}

三方晶系に属するカルサイト型炭酸塩の加熱分解反忘 在単結晶X線法を用いて結晶学的に考察した研究は極め て少尔い. Glasser 5 ${ }^{14)}$ は炭酸塩鉱物の加熱分解につい て総括し, $\mathrm{FeCO}_{3}{ }^{15}, \mathrm{ZnCO}_{3}{ }^{16)}$ はトポ多キシーの関係を 保って分解するのに対して，カルサイト年をとドロマイ ト ${ }^{17}$ はトポタキシーの関倸老伴わないと述へてている。 Haul ら ${ }^{18)}$ はドロマイトの熱分解の機構老単結晶X線法 で研究し， $600^{\circ} \mathrm{C}$ では先ず监結晶的班点を与える方位性 のカルサイトと粉末リングを与えるマグネシアに分解し $800^{\circ} \mathrm{C}$ ではさらに方位性のカルサイトは分解し，方位性 のないカルシアとマグネシアになると報告している。し 加し, Hyatt ら ${ }^{17}$ は炭酸ガス雾囲気の中で, カルサイト の加熱隇量速度の解析加らとのカル少イトと類似の䡔 造をもつ準安定の活性 $\mathrm{CaO}$ が先ず生成し, 次にカルシ アに変化すると述べている。マグネ少イト分解の機構に 関しての報告は知られていない上らである。

図-3 の走査型電子顕微鏡写真に示されている単結晶 マグネサイトから晶出したマグネシアは，加熱蕰度が $1100^{\circ} \mathrm{C}$ を越す上, 粒子が配向性をもっているように思 われる。应た, $1100^{\circ} \mathrm{C}$ 付近の温度でマグネ少イト仮像内 のマグネシア粒子が互に結合しはじめるのに対し，マグ

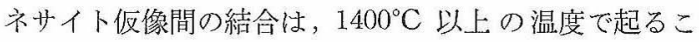
とが観察された。

図-4の電子回折像にはマグネシアの 110 の逆格子が 認められ，2つの 110 の逆格子が互に (110) 面内で約 15 度をなしている。

図-5 に示した振動写真には，マ グネシアの (200) と (220) のデバイ 環に沿った弧状の斑点が現われてい る。これによって，晶出したマグネ シアは高度の配向性を持っているこ とがわかる。

本害験に用いた合成マグネサイト の加熱分解によって生じたマグネシ アの粒子の成長とその焼結の㴍相 は，晶出したマグネシアが高度の配 向性を保っており，またもとのマグ ネサイトの結晶軸に対して共軸関係 起保っているものと考えられるの でこの分解反応はトポタキシー的 な反応であり, また, 走查型電子顕 
微鏡観察から認もられるように，分解反忘の過程で，も とのマグネサイトの仮像に無数の空隚が生じているの で, このマグネサイトの分解反応は $\mathrm{FeCO}_{3}$ や $\mathrm{ZnCO}_{3}$ の場合と同じよらに不均一機構によるであろうと考えら れる. 本実験に用いた試料は結晶性が良くかつ結晶がか なり大きいので, 空気中の加熱でも $\mathrm{CO}_{2}$ が結晶内に保 持され, $\mathrm{Mg}$ イオンと陰イオンとの拡散が充分に起りう るので, 結晶の粒子が比較的低い温度で発達するものと 考えられる。

\section{5. 総括}

合成したマグネサイト結晶を空気中で $450^{\circ} \sim 1500^{\circ} \mathrm{C}$ の間に加熱し, 生成したマグネシアを粉末 X線法, 単結 晶X線法ならびに走查型電子顕微鏡観察により, その加 熱変化と焼結の過程を検討した.

もとのマグネサイトの菱面体の仮像は $1500^{\circ} \mathrm{C}$ に加熱 したものにおいても保たれていた. $1000^{\circ} \mathrm{C}$ まの加熱で は, 仮像内のマグネシアの粒成長が主であり， $1100^{\circ} \mathrm{C}$ は，仮像内のマグネシア粒子が互に結合しはじめ，1400 ${ }^{\circ} \mathrm{C}$ では仮像間の結合が観察された.

X線で測定したこのマグネシア結晶子の大きさと, 走 査型電子顕微鏡で観察した粒子の大きさは, 従来報告さ れている試薬の炭酸マグネシウムや天然マグネサイトを 加熱して生成したものに比べて $1000^{\circ} \mathrm{C}$ までは大差はな いが, $1300^{\circ} \mathrm{C}$ 付近では急激に成長することが認められ た.

マグネサイト結晶から晶出するマグネシアは, もとの マグネサイトと高度の方位性を保っていることが見出さ れた.

このマグネサイトの分解反応は, 単結晶 $\mathrm{X}$ 線の実験か ら晶出したマグネシアともとのマグネサイトと共軸関係
を保っているので, トポタキシ一的な反応であり, 分解 過程で無数の空隚が生じることからこの反応は不均一反 応機構によるものと考えられる。

\section{女 献}

1) A. Pande, R. Singh, J. Am. Ceram. Soc. $41[10]$ 394-97(1958).

2) A.U. Daniels, Jr., R.C. Lower, Jr., R.L. Gibby, I.B. Cutler, ibid. 45 [6] 282-84 (1962).

3) 橋本栄久, 永戸泰三, 工業化学雑誌 62 [10] 1478-81 (1959).

4) W. Münchberg, R. Blaschke, K. Obst, Haus der Technik-Vortragsveröffen-tlichungen Hichungen 247, 46-57 (1970).

5) K. Oh, H. Morikawa, S. Iwai, H. Aoki, Am. Mineral. 58, 339-40 (1973).

6) F.W. Jones, Proc. Roy. Soc. (London) 166 A, 16-42 (1938).

7) L. Alexander, J. Appl. Phys. 25 [2] 155-61 (1954).

8) P. Scherrer, Nach. Gesell. Wiss. Göttingen, Zitzungsber., July 26, (1918).

9) A.L. Patterson, Phys. Rev. 56, 972 (1939).

10) L.S. Birks, H. Friedman, J. Appl. Phys. 17 [8] 687 $-92(1946)$.

11) A. Cimino, P. Porta, M. Valigi, J. Am. Ceram. Soc. 49 [3] 152-56 (1966).

12）桜井敏雄, 結晶解析 ユニバーサルプログラムシステム (II), 日本結晶学会 (1967) p. 99-205.

13) W.R. Eubank, J. Am. Ceram. Soc. 34 [8] 225-29 (1951).

14) L.S. Dent Glasser, F.P. Glasser, H.F.W. Taylor, Quarterly Reviews 16, 343-60 (1962).

15) J.D. Bernal, D.R. Dasgupta, A.L. Mackay, Clay Minerals Bull. 4, 15 (1959).

16) A. Rose, Compt. Rend 208, 1914 (1939).

17) E.P. Hyatt, I.B. Cutler, M.E. Wadsworth, J. Am. Ceram. Soc. 41 [2] 70-74 (1958).

18) R.A.W. Haul, H. Wilsdorf, Acta Cryst. 5 [5] 25055 (1952).

(11/12/1973 受付) 